\title{
Use Of Augmented Reality As A Learning Media In Early Childhood Education Solideo Perumnas I Jayapura
}

Remuz MB Kmurawak, M.T ${ }^{1}$,Diana Setyaningsih, M.Pd ${ }^{2}$

1,2 Cenderawasih University

\section{ABSTRACT}

Learning media for young children is a tool used to introduce the theme as teaching materials or what is often called the curriculum for early childhood. The more sense tools are involved in the learning process, the more likely the child understands the information presented by the teacher. Recently, learning media still uses face to face methods or books. Meanwhile, early childhood is easily bored and more interested in new things. This research aims to develop a Learning media that used to introduce animals using Augmented Reality (AR) so that children can know the environment and food needed by the introduced animal. $83 \%$ of teachers and $91 \%$ of students enjoy using the application in animal recognition..

\section{KEY WORDS}

learning media, animal recognition, augmented reality, mobile phone

\section{CORRESPONDING AUTHOR:}

email: remuzbertho3@gmail.com@ums.ac.id

Manuscript submitted May 21, 2020; accepted June 17, 2020.

Copyright: @2020 This is an open access article under the terms of the Creative Commons Attribution License, which permits unrestricted use, distribution, and reproduction in any medium, provided the original author and source are credited.
ECRJ (Early Chilhood Research Journal)

ISSN Numbers: Print, 2655-6448; Online, 2655-9315

\section{ADDRESS}

Website: http://journals.ums.ac.id/index.php/ecrj

Address: Pendidikan Guru PAUD

Universitas Muhammadiyah Surakarta

A. Yani Street No. 1, Pabelan, Kartasura, Surakarta, Indonesia Telp. +62-271-717417 ext.

Email: ecrj@ums.ac.id

\section{INTRODUCTION}

Early childhood education focuses on children aged 0 to 6 years who get early childhood education and primary school education services. This golden period commonly referred to the child's brain's ability to learn new things.

During this period they are getting more sensitive to stimulus-response, furthermore they easier on learning new things, and adaptable to new interesting things. So, it seems to be important for children at this age to learn about living creature around them, one of them is learning about animals. Media about animal introduction for kindergarten students, such as a book with two-dimensional animal form, seems like incapable yet of exciting children on learning about animal species

There are six aspects of development that can stimulate in early childhood education. Namely aspects of moral and religious development, aspects of physical motor development, aspects of language development, aspects of emotional, social development, aspects of cognitive 
development and aspects of artistic development. (Zaini \& Dewi, 2017)

In the Law on the National Education System, early childhood education is a coaching effort aimed at children from birth until the age of six carried out through the provision of educational stimuli. This education aims to help physical and spiritual growth and development so that children have a readiness to enter more education continued (Law Number 20, 2003)

In the Law on National Education System, an early childhood education development efforts since the baby until the age of six years.

coaching effort aimed at children from birth to the age of six years which is carried out through the provision of educational stimuli to help physical and spiritual growth and development so that children have a readiness to enter education more information (Law Number 20, 2003)

Augmented Reality is the concept of merging the virtual world into the real world. The creation of the virtual world is done to arouse the user's perception of understanding information from recognized objects. Augmented Reality is defined as the use of realtime digital computers and other special hardware and software to produce a simulated world or alternative environment, which is believed to be real or true to users (Hincapié, Caponio, Rios, \& González Mendívil, 2011)

This study aims to develop learning media by utilizing Augmented Reality technology so that the teaching and learning process is more interesting because it can display threedimensional objects that can resemble the original form. The learning media in this study is aimed at early childhood who join the KB so that children can see, pronounce, touch to change the size of the object, and can rotate the object displayed. This research involved PAUD Solideo Perumnas 1 Jayapura. to test user satisfaction by using indicators of success including the ability of children to be able to recognize animal objects from their environment, the ability of children to name the animals of the objects displayed, children's interest in using $A R$ compared to using Educational Aids (APE) and satisfaction children to the appearance of objects to the user's touch, where children can touch objects to change the size of the object and rotate the object by 3600

\section{MEDIA}

Media is everything that can be used to channel messages from the sender of the message to the recipient of the message so that it can stimulate the thoughts, feelings, attention, and interests and attention of young children in such a way that the learning process occurs. While according to Dhine, 2012: 205 states that the media is originated from the plural word medium, meaning intermediate. Besides, the media is also interpreted as something that is located in the middle. The point here is an intermediary that connects all parties who need a relationship and distinguishes between communication media and communication aids.

Meanwhile, according to the association for education and communication technology (AECT) in Dhini et al, 2007 the media are defined as all forms used for a process of 
information distribution. Education Association (NEA) in Dhini et al, 2007 defines the media as objects that can be manipulated, seen, heard read and discussed along with instruments used both in teaching and learning activities that can affect the effectiveness of instructional programs. The media is an intermediary of the message from the sender to the recipient. It can stimulate the thoughts, feelings and attention of students for the achievement of educational goals. From some of the above theories, we can conclude that learning media is very important, as according to Harjonto (2010: 43). Teaching media is divided into two parts, namely media in the narrow sense and media in the broad sense. In the narrow sense, the teaching media only includes media that can be used effectively in a planned teaching process, whereas in a broad sense, the media not only includes complex electronic communication media but also includes simple tools such as slides, photographs, diagrams and charts teacher made.

\section{RESEARCH METHOD}

\section{Type and Research Method}

Type of the research is quantitative research with a survey method. Analysis of the data will be done quantitatively with a simple statistic technique.

\section{Research Site}

The research site is in Solideo Early Childhood Education in Jayapura. The implementation time is on $15-16$ November 2019.

\section{Research Subject}

The research subject is students at kindergarten as many as 12 students.

\section{Method of Collecting Data}

The method of collecting data in this research is the test method and also observation. This research begins with a literature study and interviews about relevant material that can be used as learning media. A literature study is carried out to find a picture of the desired object. For markers on AR in the form of markers, the authors use physical images that are designed by the 3D Object researchers themselves. Markers in the form of animal recognition images use a printer with a maximum print resolution of $5760 \mathrm{dpl}$. Images with a size of 1028px x 1954px produce prints that exceed $A 5$ paper size so that the image is reduced by $25 \%$ of the original image to get prints that can be loaded on A5-size paper.

The process of designing an AR application follows the following stages. The first stage begins with the selection of trackable models. The marker model is divided into three forms of tracking, namely; image tracking, object tracking, and environmental tracking. Then the selected marker is then rendered or merged the image with the environment, which is then saved into the AR Store. The next process is the process of displaying 3D objects. 


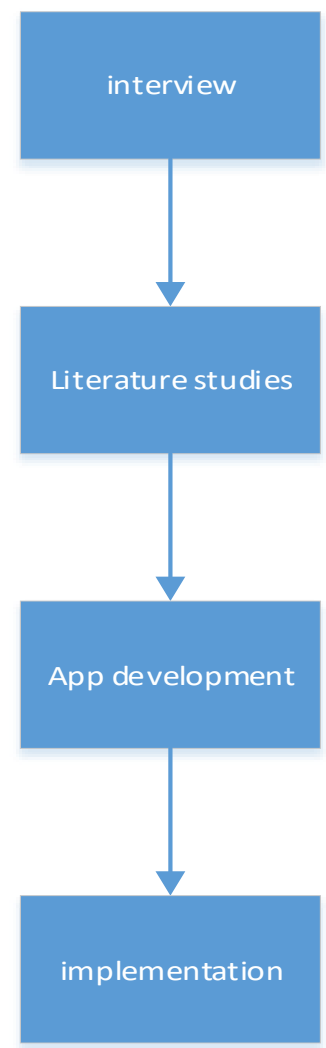

Figure 1. Research Methodology

\section{The technique of Data Analysis}

Analysis technique in this research is the descriptive statistic used, like 1) Data presentation is in the form of table or frequency distribution and cross-tabulation. 2) Data presentation is in the form of visual like histogram, polygon, ogive, bar chart, pie chart, pastel diagram, and symbol diagram; 3) Calculation of the size of (mean, median and modus); 4) size calculation (quartile, decile, percentile); 5) deployment size calculation (Sudjana 1994, 30). critical observation, concentration, memory, the notion of objects and assessment toward the situation, and understanding story and pictures of people.

\section{RESULTS AND DISCUSSION}

\section{Result}

Making 3D using blender software. This 3D will be displayed on the mobile phone, after determining the marker

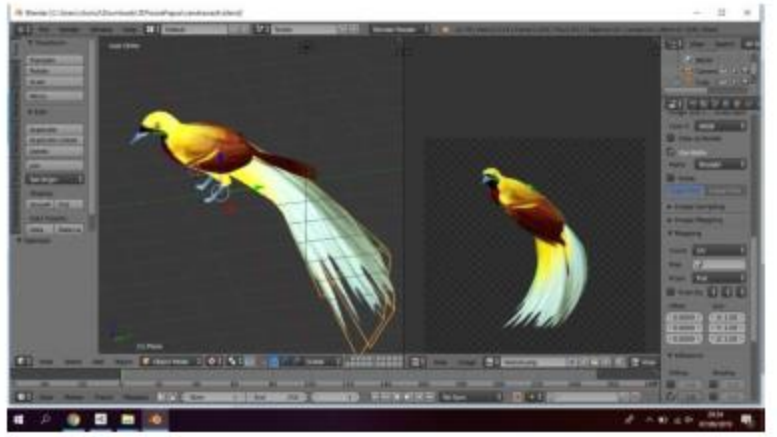

Figure 2. Create a 3D Model

$3 d$ animals will be displayed when the object used as a marker is detected by the camera

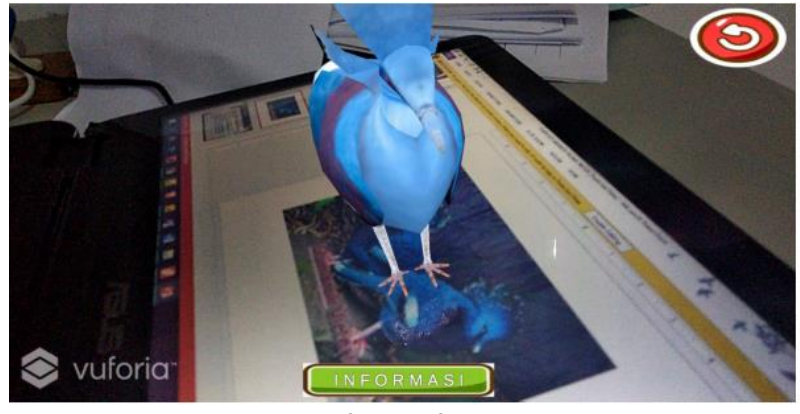

Figure 3 Marker and 3D

\section{CONCLUSION}

After presenting the mobile-based software, $83 \%$ of teachers and $91 \%$ of students enjoy using the application in animal recognition. In this software, there are four endemic animals in Papua. This application has helped students to get to know and understand these animals. As input for the teacher hopes that there is the dynamic movement of each object so that it can provide a more detailed description to students. 


\section{REFERENCES}

Hincapié, M., Caponio, A., Rios, H., \& González Mendívil, E. (2011). An introduction to Augmented Reality with applications in aeronautical maintenance. International Conference on Transparent Optical Networks.

https://doi.org/10.1109/ICTON.2011.597 0856

Undang-Undang Nomor 20. Sistem Pendidikan Nasional (2003).

Zaini, H., \& Dewi, K. (2017). Pentingnya Media Pembelajaran Untuk Anak Usia Dini. Raudhatul Athfal: Jurnal Pendidikan Islam Anak Usia Dini, 1(1). Retrieved from http://jurnal.radenfatah.ac.id/index.php/r audhatulathfal/article/view/1489 